\title{
Production of Non-Structural Concrete Using Different Types of Waste Materials
}

\author{
Asst. prof. Aamer Najim Abbas* and Eng. Hussain Haider Abdulzahra \\ Department of Civil Engineering, Al-Muastansiriya University, Baghdad 00964, Iraq
}

\begin{abstract}
As a result of industrial and urban development witnessed by the world in a lot waste, which has always been great problem because of their accumulation in large quantities, the need arises to take advantage of this waste in other industries such as concrete industry. In this study, the effect of the replacement of coarse aggregate by the waste materials has been discussed. Four types of waste materials have been used, these materials are plastic, electrical wires, styropor and foam. Different ratios of these materials have been used to study its effect on the compressive strength and tensile strength of concrete and tested for 3, 7 and 28 days. The results compared with the reference specimens and study the relationship between the compressive and tensile strength on one hand and the ratios of these materials on the other hand.
\end{abstract}

Keywords: Plastic, styropor, foam, steel wire, compressive strength, tensile strength.

\section{Introduction}

The obsession with researchers in the past decades was the discovery of a new type of low price concrete comparable to what was used classical concrete. Here came the idea of exploiting the existing remnants of every day human waste and residues of factories.

Many researches were conducted to use waste materials in concrete industry. Khilesh sarwe [1] used waste plastic and steel fiber in concrete mix, discussed the effect of adding these materials on compressive and tensile strength of concrete, and found that the use of plastics lowered the strength of resultant concrete. Also, Raghatate Atul M. [2] studied the use of plastic to improve strength of concrete and found that the compressive strength is affected by addition of plastic pieces, the compressive strength decreased about 20\% when adding $1 \%$ of plastics pieces. The decrease in tensile strength was also observed in this study.

Mohd H. A. et. al. [3] produced lightweight concrete by using Styrofoam with the other concrete components. In this study, they showed that concrete

*Corresponding author: Aamer Najim Abbas, assistance professor, research field: engineering. E-mail: amir_najim@yahoo.com. series of using $10 \mathrm{~mm}^{2}$ size styrofoam aggregates with $10 \%$ coarse aggregate replacement level gave highest compressive strength in long-term up to 180 days.

Semsi Y. and Hasan S. [4] studied the effect of fly ash on the compressive and tensile properties of concrete. They found that the highest values of the compression and splitting tensile strengths of the concretes produced with fly ash additives are obtained with $5 \%$ replacement rates of the flyashes. It was seen that as the replacement rate increased, compressive and splitting tensile strengths decreased. Satish D. et. al. [5] studied the effect of adding fly ash and rice husk ash on concrete, they found that the produced concrete have a good compressive strength and workability in comparison with reference specimens, and also found that the tensile strength was decreased.

\section{Reasons of Using The Waste Materials in Concrete Production}

\subsection{Using a Plastic Pieces}

Waste materials which are used for packaging the food, water and juice or as a packaging tools to save the production during handling and transporting may be considered one of the most important environmental 
problems, because the accumulation of these residues helps bacteria and germs to grow, posting a great danger to living organisms including human. From here came the idea of getting rid if this waste by making use of them in the concrete industry at the same time to rid the environmental from dangerous pollutant.

The idea of replacement plastic pieces instead of coarse aggregate in nonstructural concrete is good in principle if and only if get a compressive strength similar the other construction materials such as bricks or thermo stone. Because it can be used as a good alternative to this material being lightweight and a reasonable bearing for purpose of partition only, especially if was cutting in the large pieces as it proved a good speed of accomplishment in addition to the previously mentioned properties.

\section{Materials}

\subsection{Cement}

Cement used in casting the specimens of this study is ordinary Portland cement. The properties of cement are listed in Table 1.

\subsection{Fine Aggregate}

Clean river sand used as a fine aggregate. The properties of fine aggregate are listed in Tables 2 and 3.

\subsection{Coarse Aggregate}

The ideal coarse aggregate used for the production of non-structural concrete should be clean and angular. The maximum coarse aggregate size used in this study is chosen to be $14 \mathrm{~mm}, 100 \%$ crushed aggregate.

Crushed gravel from local region with specific gravity and absorption of 2.64 and $0.57 \%$ respectively is used. Table 4 shows the grading of this aggregate.

\subsection{Plastic}

Plastic pieces which used for the packaging water are used in concrete instead of coarse aggregate. See Fig. 1.
Table 1 Cement properties.

\begin{tabular}{lll}
\hline & Properties & Test result \\
\hline 1 & Specific gravity & 2.93 \\
2 & Initial setting time (min.) & 150 \\
3 & Final setting time (min.) & 205 \\
4 & Compressive strength $\mathrm{N} / \mathrm{mm}^{2}$ (3 days) & 8.7 \\
5 & Compressive strength $\mathrm{N} / \mathrm{mm}^{2}$ (7 days) & 16.73 \\
\hline
\end{tabular}

According to the American standard ASTM. C150 [6].

Table 2 Physical properties of fine aggregate.

\begin{tabular}{lll}
\hline & Properties & Test result \\
\hline 1 & Water absorption & $0.58 \%$ \\
2 & Specific gravity & $2.46 \%$ \\
3 & Fineness modulus & 2.5 \\
4 & Moisture content & $0.23 \%$ \\
\hline
\end{tabular}

Table 3 Sieve analysis of fine aggregate.

\begin{tabular}{ll}
\hline Sieve size & Passing ratio (\%) \\
\hline 9.5 & 100 \\
4.75 & 94 \\
2.36 & 82 \\
1.18 & 66 \\
0.6 & 24 \\
0.3 & 14 \\
0.15 & 1 \\
\hline
\end{tabular}

Table 4 Sieve analysis of coarse aggregate.

\begin{tabular}{ll}
\hline Sieve size $(\mathbf{m m})$ & \% Passing by weight \\
\hline 20 & 100 \\
14 & 99 \\
10 & 57 \\
5 & 4.5 \\
2.36 & 0 \\
\hline
\end{tabular}

\subsection{Wire}

Electrical wire pieces which used for the building electrical work are used in concrete instead of coarse aggregate. See Fig. 2.

\subsection{Foam}

Foam pieces which used for the building construction are used in concrete instead of coarse aggregate. See Fig. 3.

\subsection{Styropor}

Styropor pieces which used for the packaging goods and other housewares like dishes and cups are used in 
concrete instead of course aggregate. See Fig. 4.

\section{Experimental Program}

\subsection{Compressive Strength Test}

Cubical $100 \times 100 \times 100 \mathrm{~mm}^{3}$ specimens were used to test compressive strength of concrete for 3, 7 and 28 days. The compressive test was done according to ASTM C39 [7] and BS1881 [8] by using a computerized machine with a capacity of $1000 \mathrm{KN}$.

\subsection{Tensile Strength Test}

The splitting tensile strength is determined for 3,7 and 28 days on cylinder measuring $(150 \times 300) \mathrm{mm}^{2}$ according to BS1881-117 [9].

\section{Results and Discussion}

\subsection{Effect of Plastic Pieces}

In general, there is a decrease in the compressive strength of concrete cubes as a result of replacement pieces of plastic with coarse aggregate. The amount of decrease in the compressive strength is about (33.63, 48.63 and 60 )\% when using (50, 66 and 85 )\% of plastic pieces respectively, this decreases in compressive strength may be due to weak interaction between the concrete components as a result of surface smoothness and lack of sharp corners in the plastic pieces enough to secure the interaction between them and other concrete component see Fig. 5 and Table 5 below.

Tensile strength is considered one of the important properties of concrete, when improved tensile strength properties of concentrate reduces somewhat the proportion of reinforcement in the concrete section, because there is a percentage of the tensile stresses carried by concrete.

In this study, it was observed an improvement in tensile strength of concrete when using plastic pieces instead of course aggregate. It was observed that the improvement in tensile strength of concrete about (3.87, 6.77 and 1.93$) \%$ when using $(0.50,0.66$ and 0.85$) \%$ pieces of plastic respectively. This improvement is may

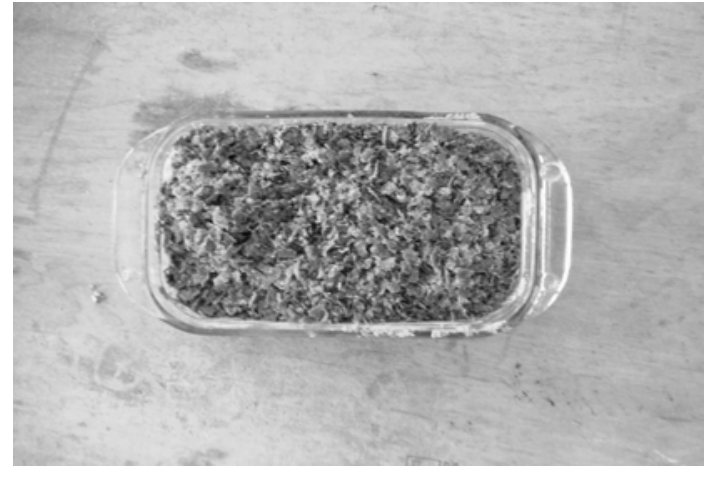

Fig. 1 Plastic pieces.

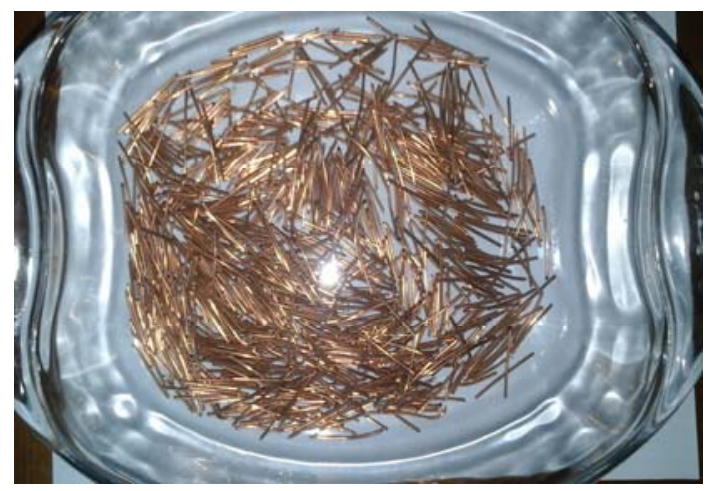

Fig. 2 Wire pieces.

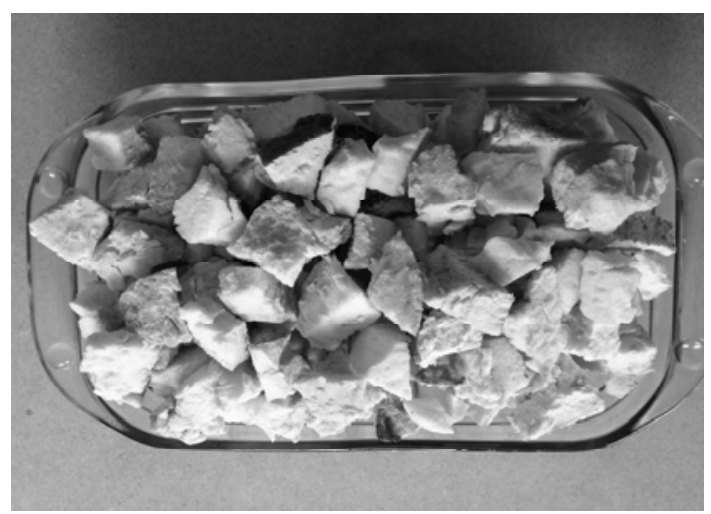

Fig. 3 Foam pieces.

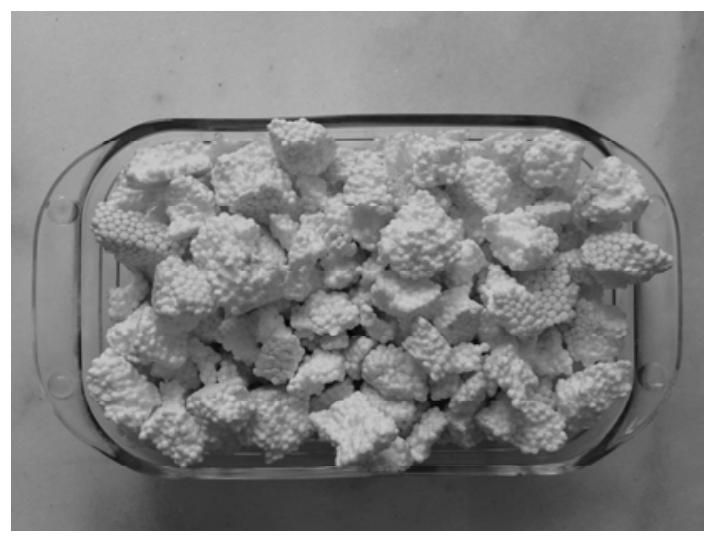

Fig. 4 Styropor pieces. 


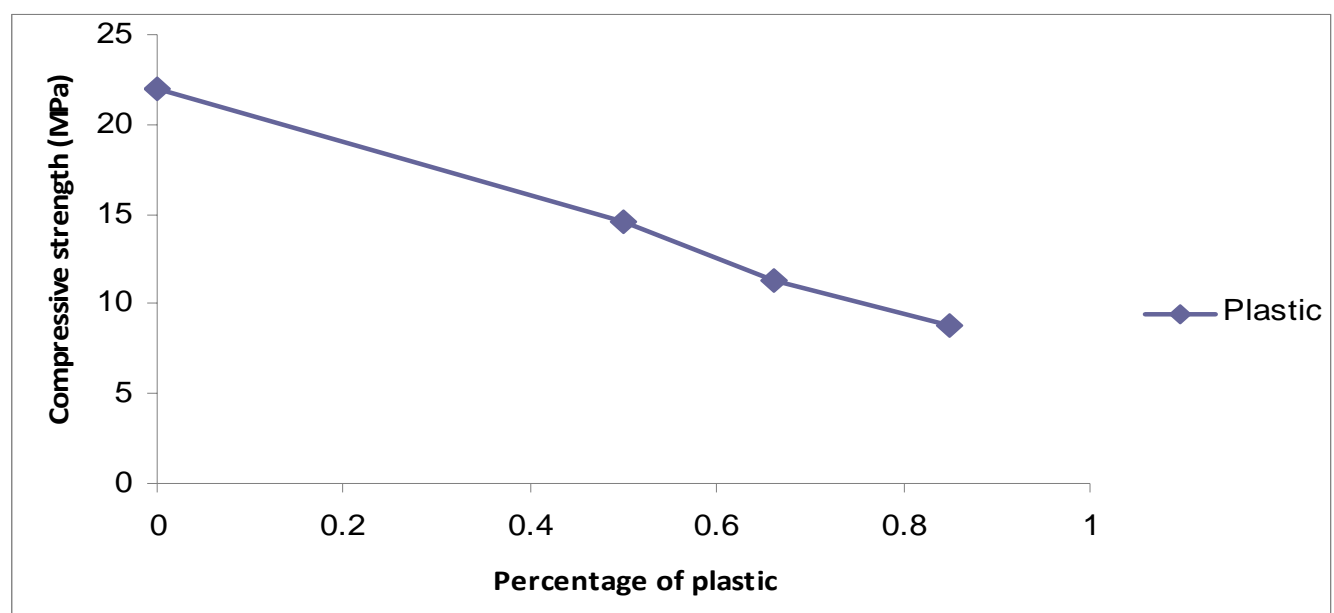

Fig. 5 Relationship between percentage of plastics pieces to compressive strength.

Table 5 Compressive strength readings.

\begin{tabular}{lllllll}
\hline $\begin{array}{l}\text { Percentage of } \\
\text { plastic (\%) }\end{array}$ & $\begin{array}{l}\text { Com. strength (MPa) } \\
\text { 28 days }\end{array}$ & $\begin{array}{l}\text { Percentage of } \\
\text { difference (\%) }\end{array}$ & $\begin{array}{l}\text { Com. strength (MPa) } \\
7 \text { days }\end{array}$ & $\begin{array}{l}\text { Com. strength (MPa) } \\
3 \text { days }\end{array}$ & $\begin{array}{l}\text { Dry density } \\
{\mathrm{g} / \mathrm{cm}^{3}}^{3}\end{array}$ & $\begin{array}{l}\text { Percentage of } \\
\text { difference }(\%)\end{array}$ \\
\hline 0 & 22 & - & 15.9 & 9.52 & 2.34 & - \\
0.5 & 14.6 & 33.63 & 8.69 & 4.91 & 1.71 & 26.92 \\
0.66 & 11.3 & 48.63 & 7.81 & 4.25 & 1.81 & 22.64 \\
0.85 & 8.8 & 60 & 5.92 & 3.56 & 1.73 & 26 \\
\hline
\end{tabular}

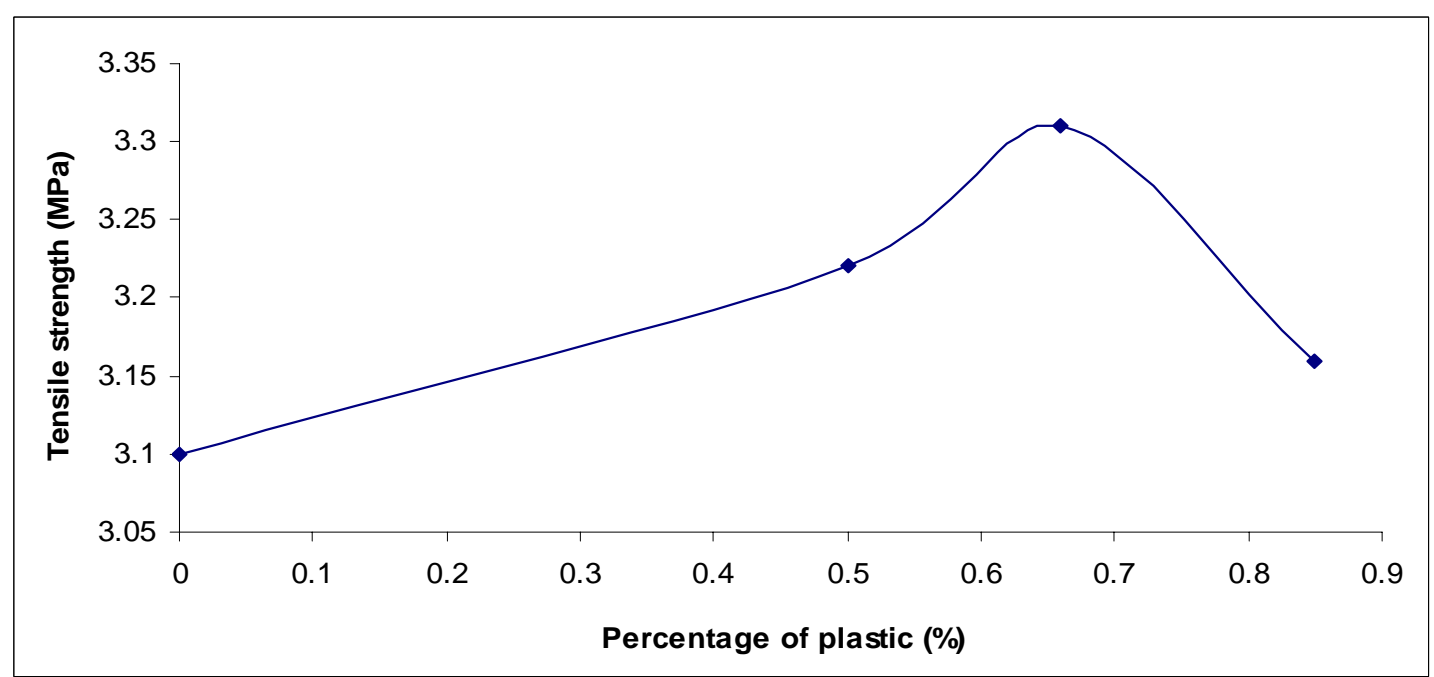

Fig. 6 Relationship between percentage of plastics pieces to tensile strength.

Table 6 Tensile strength readings.

\begin{tabular}{lll}
\hline Percentage of plastic (\%) & Tensile strength (MPa) & Percentage of difference (\%) \\
\hline 0 & 3.1 & - \\
0.5 & 3.22 & 3.87 \\
0.66 & 3.31 & 6.77 \\
0.85 & 3.16 & 1.93 \\
\hline
\end{tabular}

be due to that the plastic pieces make as a bridge to connect the two sides of cracks when propagate through the concrete cube. See Fig. 6 and Table 6.
The ductile failure of concrete cubes is clear by using plastic pieces, this is also one of the important gains in the concrete development. 


\subsection{Effect of Styropor Pieces}

Lightweight concrete is one of the good solution to reduce weight of buildings thus reduce the overall cost of construction by reducing loads on beams, columns and foundations.

In this study, the creation of lightweight concrete by mixing (43, 50 and 60 )\% styropor instead of coarse aggregate were obtained compressive strength about 16.21, 14.4 and 8.92 respectively. the compressive strength obtained approach to some extent to compressive strength of the cement paste, meaning that the styropor particles worked only as a bubble inside the concrete block. See Fig. 7 and Table 7.

The same case applied to the tensile strength of the concrete model, as it was noted that there is a significant decrease in the tensile strength when using styropor, due to weakness of the styropor to resist tensile stresses on the concrete sample. See Fig. 8 and
Table 8.

\subsection{Effect of Steel Wires}

The use of steel fiber is one of the important ways to develop the tensile strength of concrete, where these fibers are working on linking the concrete mix components and work as obstacles to resist the growth of cracks in the concrete block.

As shown in the Fig. 9 and Table 9, the replacement of steel wire instead of coarse aggregate produces concrete with good compressive strength 19.6, 22.2 and 17.9 when adding (43, 50 and 66)\% steel wire respectively.

The advantages of using the pieces of electrical wire inside the concrete as a steel fiber reflected in the development of tensile strength, and this is certain clearly in this research as increased tensile strength by (17.6, 31.55 and 14.6$) \%$ when adding (43, 50 and 66$) \%$ of the wires. See Fig. 10 and Table 10.

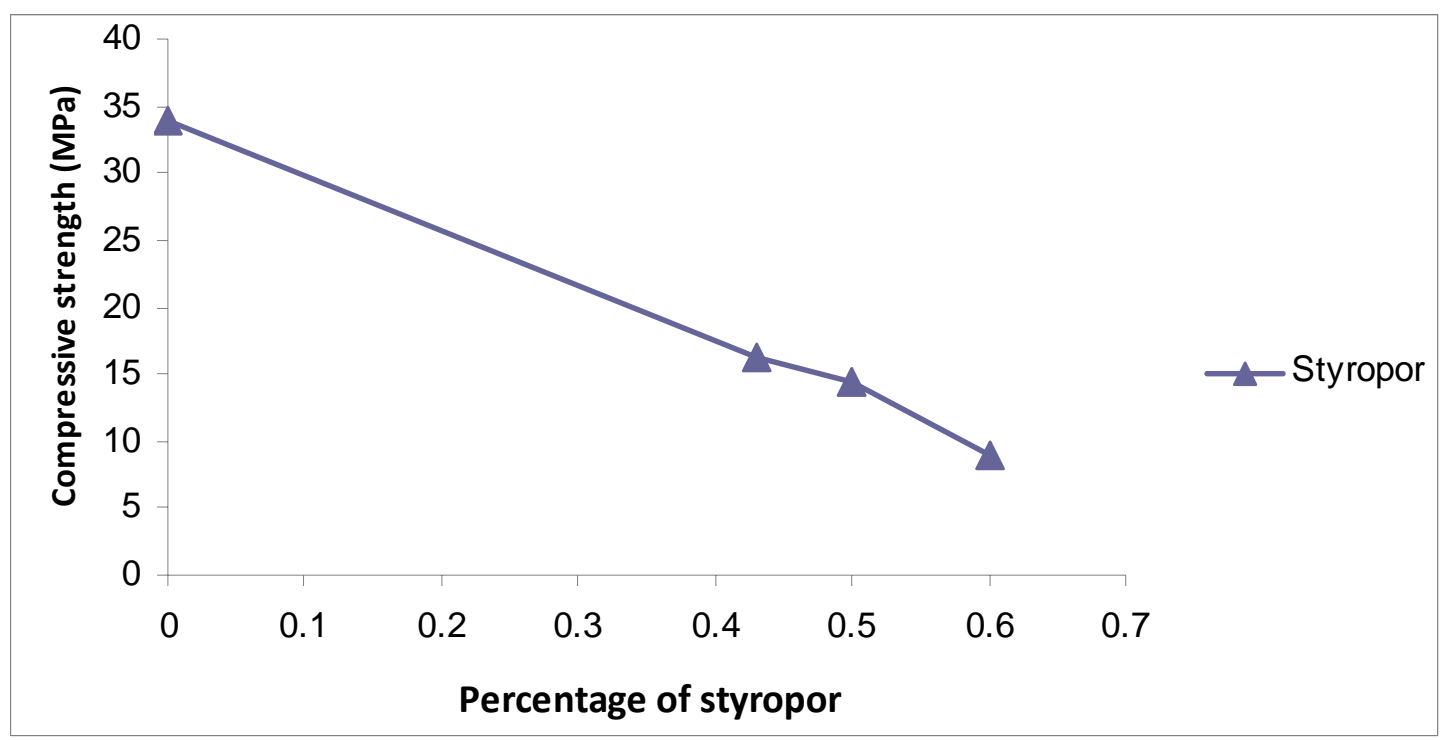

Fig. 7 Relationship between percentage of styropor pieces to compressive strength.

Table 7 Compressive strength readings.

\begin{tabular}{lllllll}
$\begin{array}{l}\text { Percentage of } \\
\text { styropor (\%) }\end{array}$ & $\begin{array}{l}\text { Com. } \\
\text { strength (MPa) } \\
\text { 28 days }\end{array}$ & $\begin{array}{l}\text { Percentage of } \\
\text { difference (\%) }\end{array}$ & $\begin{array}{l}\text { Com. } \\
\text { strength (MPa) } \\
\text { 7 days }\end{array}$ & $\begin{array}{l}\text { Com. } \\
\text { strength (MPa) } \\
\text { 3 days }\end{array}$ & $\begin{array}{l}\text { Dry density } \\
\text { g/cm }\end{array}$ & $\begin{array}{l}\text { Percentage of } \\
\text { difference (\%) }\end{array}$ \\
\hline 0 & 34 & - & 23 & 14.3 & 2.48 & - \\
0.43 & 16.21 & 52.32 & 12.43 & 4.1 & 1.5161 & 38.86 \\
0.5 & 14.4 & 57.64 & 9.21 & 3.7 & 1.1852 & 52.2 \\
0.6 & 8.92 & 73.76 & 5.98 & 3.2 & 0.9638 & 61.13 \\
\hline
\end{tabular}




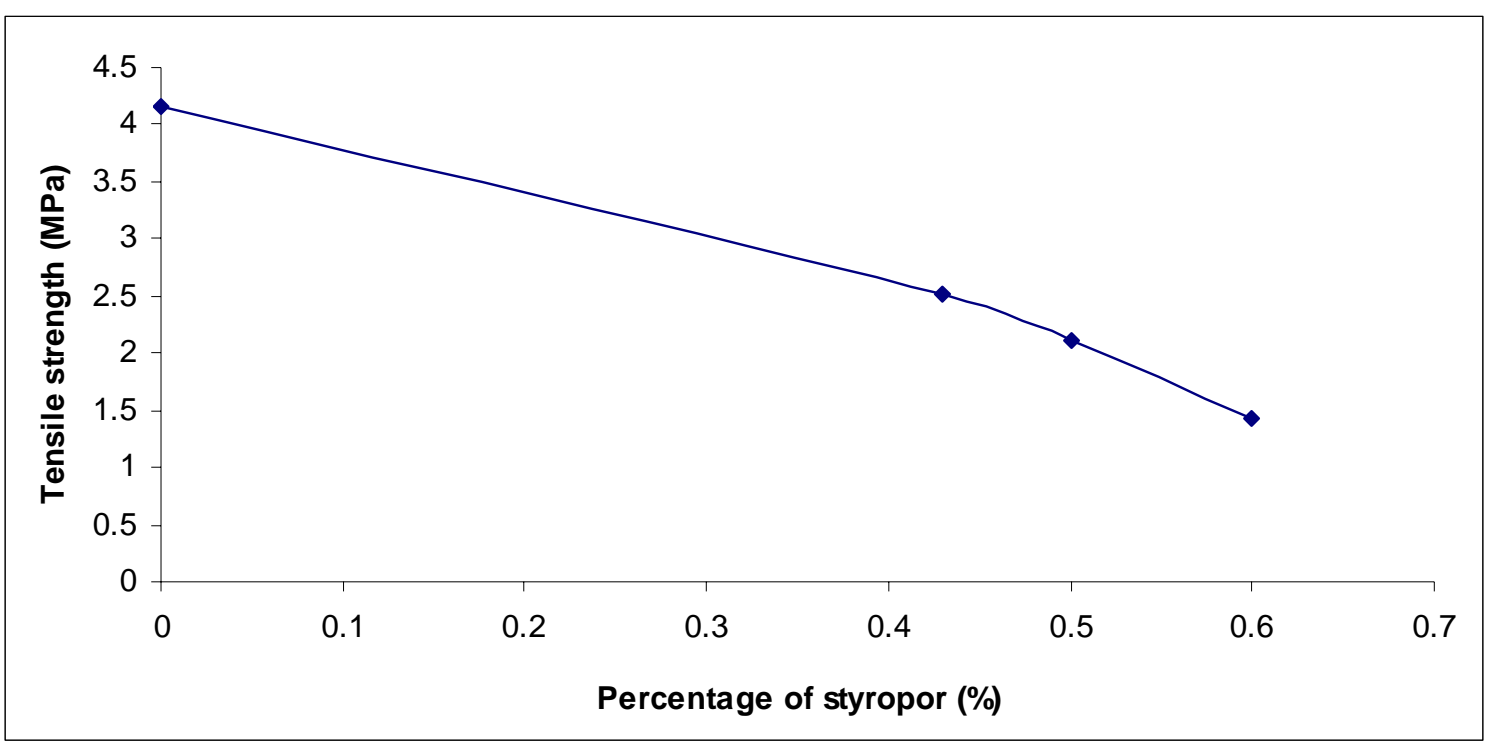

Fig. 8 Relationship between percentage of ptyropor pieces to tensile strength.

Table 8 Tensile strength readings.

\begin{tabular}{lll}
\hline Percentage of styropor (\%) & Tensile strength (MPa) & Percentage of difference (\%) \\
\hline 0 & 4.15 & - \\
0.43 & 2.51 & 39.51 \\
0.5 & 2.12 & 48.91 \\
0.6 & 1.43 & 65.54 \\
\hline
\end{tabular}

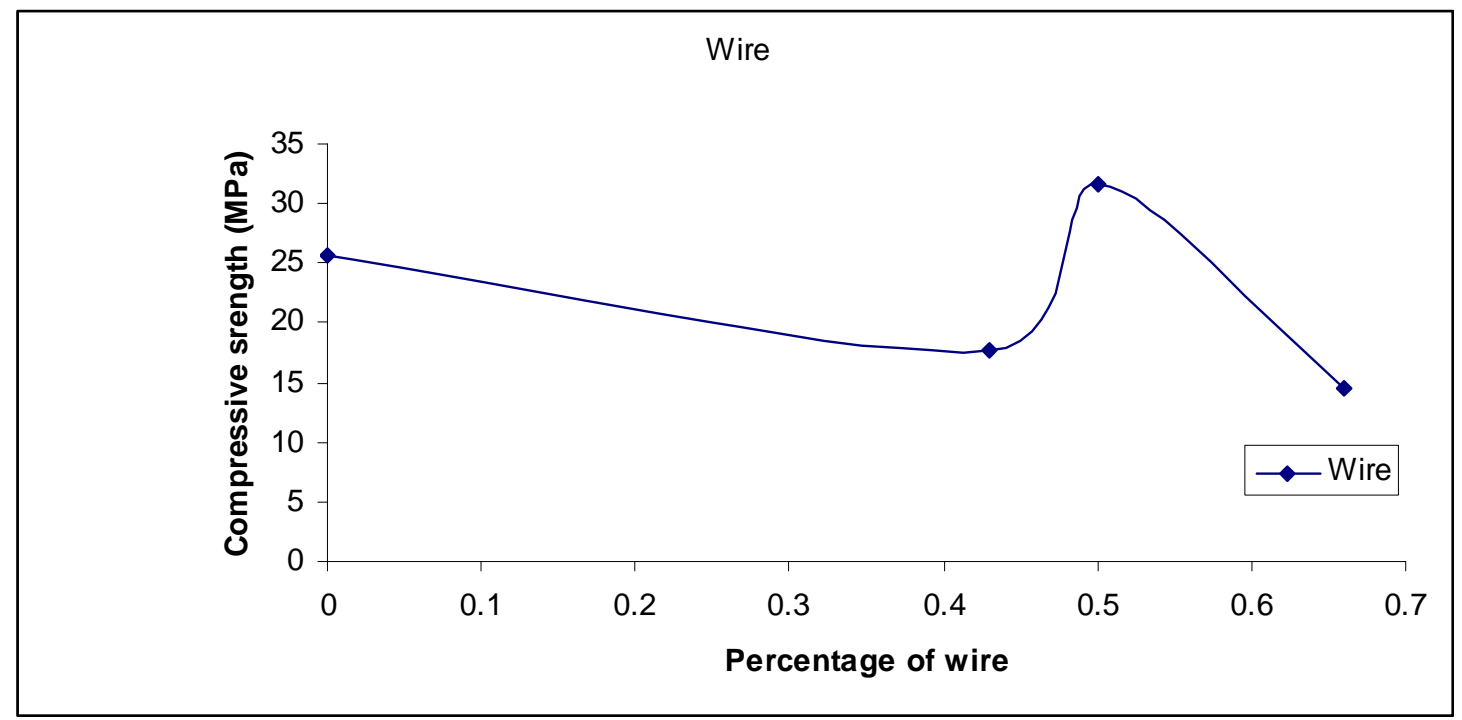

Fig. 9 Relationship between percentage of wires pieces to compressive strength.

Table 9 Compressive strength readings.

\begin{tabular}{lllllll}
\hline $\begin{array}{l}\text { Percentage of } \\
\text { wires (\%) }\end{array}$ & $\begin{array}{l}\text { Compressive } \\
\text { strength (MPa) }\end{array}$ & $\begin{array}{l}\text { Percentage of } \\
\text { difference (\%) }\end{array}$ & $\begin{array}{l}\text { Com. } \\
\text { strength (MPa) } \\
7 \text { days }\end{array}$ & $\begin{array}{l}\text { Com. } \\
\text { strength (MPa) } \\
\text { 3 days }\end{array}$ & $\begin{array}{l}\text { Dry density } \\
\mathrm{g} / \mathrm{cm}^{3}\end{array}$ & $\begin{array}{l}\text { Percentage of } \\
\text { difference (\%) }\end{array}$ \\
\hline 0 & 25.7 & - & 16.23 & 12.92 & 2.36 & - \\
0.43 & 19.6 & 23.73 & 12.52 & 4.8 & 2.31 & 2.1 \\
0.5 & 22.2 & 13.61 & 14.6 & 5.9 & 2.41 & -2.1 \\
0.6 & 17.9 & 30.35 & 14 & 7.2 & 2.46 & -4.23 \\
\hline
\end{tabular}




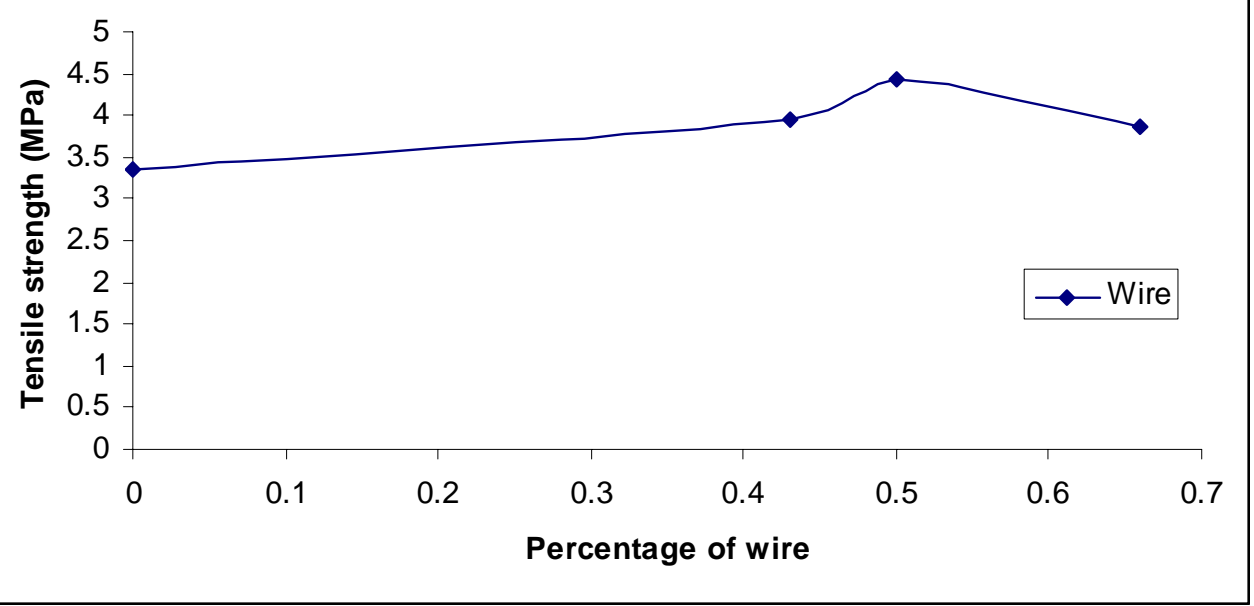

Fig. 10 Relationship between percentage of wires pieces to tensile strength.

Table 10 Tensile strength readings.

\begin{tabular}{lll}
\hline Percentage of wires(\%) & Tensile strength (MPa) & Percentage of difference (\%) \\
\hline 0 & 3.36 & - \\
0.43 & 3.95 & 17.6 \\
0.5 & 4.42 & 31.55 \\
0.6 & 3.85 & 14.6 \\
\hline
\end{tabular}

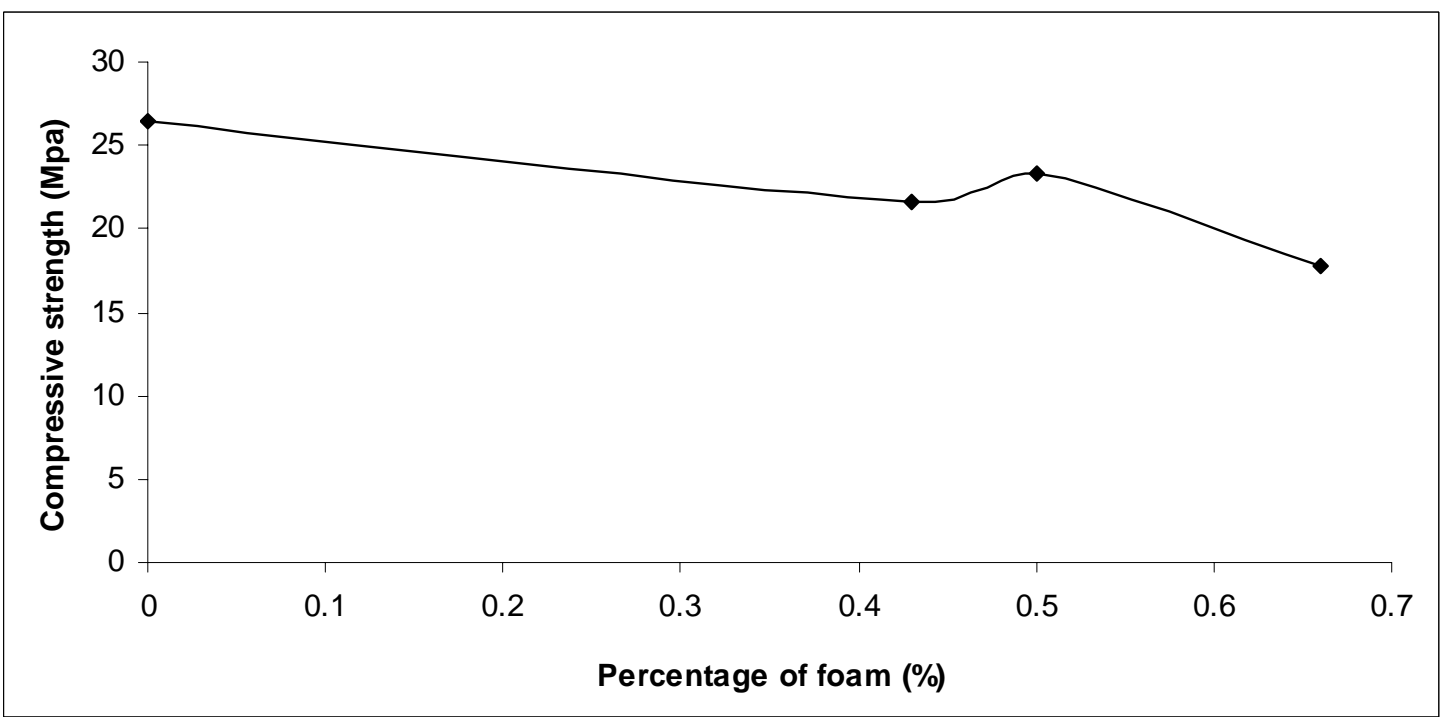

Fig. 11 Relationship between percentage of foam pieces to compressive strength.

Table 11 Compressive strength readings.

\begin{tabular}{lllllll}
\hline $\begin{array}{l}\text { Percentage of } \\
\text { foam (\%) }\end{array}$ & $\begin{array}{l}\text { Compressive } \\
\text { strength (MPa) }\end{array}$ & $\begin{array}{l}\text { Percentage of } \\
\text { difference (\%) }\end{array}$ & $\begin{array}{l}\text { Com. } \\
\text { strength (MPa) } \\
7 \text { days }\end{array}$ & $\begin{array}{l}\text { Com. } \\
\text { strength (MPa) } \\
3 \text { days }\end{array}$ & $\begin{array}{l}\text { Dry density } \\
\mathrm{g} / \mathrm{cm}^{3}\end{array}$ & $\begin{array}{l}\text { Percentage of } \\
\text { difference (\%) }\end{array}$ \\
0 & 26.4 & - & 17.7 & 13.7 & 2.41 & - \\
0.43 & 21.6 & 18.18 & 16.22 & 8.84 & 1.61 & 33.19 \\
0.5 & 23.28 & 11.81 & 18.71 & 9.97 & 1.43 & 40.66 \\
0.66 & 17.73 & 32.84 & 12.9 & 6.36 & 1.45 & 39.83 \\
\hline
\end{tabular}




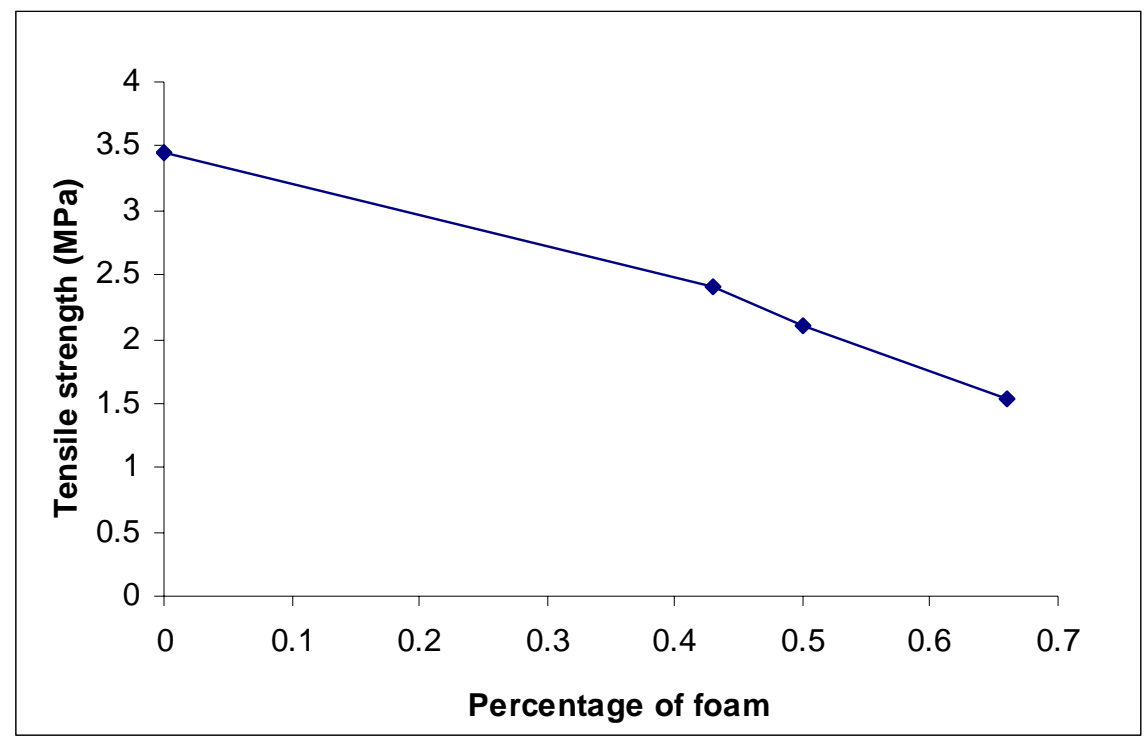

Fig. 12 Relationship between percentage of foam pieces to tensile strength.

Table 12 Tensile strength readings.

\begin{tabular}{lll}
\hline Percentage of foam(\%) & Tensile strength (MPa) & Percentage of difference (\%) \\
0 & 3.45 & - \\
0.43 & 2.41 & 30.14 \\
0.5 & 2.11 & 38.84 \\
0.66 & 1.53 & 55.65 \\
\hline
\end{tabular}

\subsection{Effect of Foam}

The use of foam instead of coarse aggregate in concrete improves the properties on concrete in the early stages of loading due to the high elasticity of the foam material.

By studying the difference in compressive strength as a result of the use of foam turns out that the amount of the decline is considered acceptable. This difference can be compensated by increasing the proportion of cement or use of a certain additives for the development of compressive strength of concrete. See Fig. 11 and Table 11.

On the other hand. There is a decrease in the tensile strength of concrete as a result of the weakness of tensile properties and bond between the foam and other components of concrete. See Fig. 12 and Table 12.

\subsection{Effect of Waste Materials on Weight of Concrete}

It is observed that when uses pieces of plastic, foam and styropor, there is a decrease in unit weight of samples. The amount of decrease in weight reach to more than $30 \%$ compared with the classical concrete. The concrete produced from these three materials (plastic, foam and styropor) are considered lightweight concrete, cheap price and friendly environment.

The decrease in the weight to this extent is a good gain economically because of its effect on the total cost of construction projects.

\section{Conclusions}

The use of plastic pieces instead of coarse aggregate in the concrete is a new development in the production of concrete. And the decrease in compressive strength can be compensated by reducing the proportion of plastic pieces in concrete.

There is a clear increase in the tensile strength of the concrete as a result of adding plastic pieces to the extent of $50 \%$ of the concrete components.

Compressive and tensile strength of the concrete affected by replacement of coarse aggregate by styropor pieces. 
There is a slight decrease in compressive strength as a result of the replacement of coarse aggregate by electrical wire.

The development of the tensile strength of concrete is an important result when replacing of coarse aggregate by electrical wires.

There is an improvement in compressive strength at early stages of loading application when using pieces of foam.

There is a decrease in compressive and tensile strength of concrete when using pieces of foam.

All kinds of concrete produced in this study are considered non-structural concrete. Therefore, we recommend using certain types of additives for the development of larger properties of concrete when thinking about the production of structural concrete.

The main benefit of this research is summarized to produce a lightweight concrete used in the partitions lighter than the classical building materials building construction, and this contribute to good extent to reduce the loads on structural elements and then reduce construction cost.

\section{References}

[1] Khilesh, S. 2014. "Study of Strength Property of Concrete Using Waste Plastics and Steel Fiber.” The International Journal of Engineering and Science 3: 9-11.

[2] Raghatate, A. M. 2012. "Use of Plastic in a Concrete to Improve Its Properties.” International Journal of Advanced Engineering Research and Studies 1: 109-11.

[3] Mohd, H. A., Lee, Y. L., Nurazuwa, M. N. and Suraya, H. A. 2008. "Strength Development of Lightweight Styrofoam Concrete.” In Proceedings of International Conference on Civil Engineering (ICCE08), 12-4.

[4] Semsi, Y. and Hasan, S. A. 2012. "Effects of Fly Ash Fineness on the Mechanical Properties of Concrete." Sadhana-Academy Proceedings in Engineering Sciences 37: 389-403.

[5] Satish, D. K., Pravin, V. D., Sandesh, D. D. and Deotale, R. S. 2015. "Assessment of Concrete Strength Using Flyash and Rice Husk Ash.” International Journal of Engineering Research and Applications 1: 524-34.

[6] ASTM C150. 2015. Standard Specification for Portland Cement. ASTM International.

[7] ASTM C39-86. 2015. Standard Test Method for Compressive strength of Cylindrical Concrete Specimens. ASTM International.

[8] BS 1881-115-1986. 1986. "Specification for Compression Testing Machines for Concrete.” BSI.

[9] BS 1881-117-1983. 1983. "Method for Determination of Tensile Splitting Strength.” BSI. 